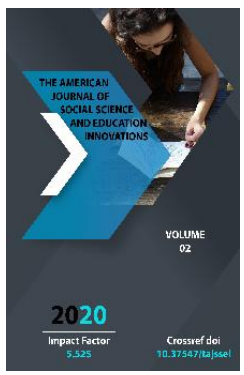

\title{
Issues Of Formation Of Rationality In Relations Of Nature With Society
}

Journal Website: http://usajournalshub.c om/index,php/tajssei

\author{
Abdumalikov Abdulatif Abidzhanovich \\ Doctor of Philosophy (PhD), Head lecturer, Ferghana State University, Uzbekistan
}

\section{ABSTRACT}

This article analyzes the formation of the ecological crisis as a result of the imbalance between society and nature, that is, nature, all matter by society.

\section{KEYWORDS}

Environmental consciousness, ecological crisis, global civilization, biosphere, Noosphere, technogenic culture, rationality.

\section{INTRODUCTION}

Global anthropological problems are formed as a result of an increase in the balance between society and nature, that is, nature, the whole mother-of-pearl society has not stepped over its ambiguous attitude, babbling, sarcasm towards itself. Now we recognize the fact that all of humanity has undergone global environmental degradation not only by great thinkers, details of science, details of economics, politics, culture, intelligentsia, but also ordinary people. Now scientists do not have a scientific basis even to put forward the idea that "the harmful impact that humanity has had on the environment can be eliminated. It is now clear whether humanity has fallen into a slowly running trap, or whether to get out of this trap ... it is quite possible that science cannot say anything 
concrete about this "come to such conclusions. Frankly speaking, now scientists predict that not only in our ecological space, but also in the "intelligent person" itself, processes will take place that will destroy him for the coming decades. Now it is difficult for humanity not to notice the scale of the destructive processes that took place thanks to its activities in the following centuries. In this sense, ecology can be described as the suffering of an awakened conscience. Indeed, the tragedy of Hiroshima, such as the Chernobyl accident, cannot be ended by counting the facts, as the unfortunate events left a deep shock in the hearts of humanity spilled, the layer became scarce, the climate is changing, rainforests are damaged, fires and floods, land, water, air pollution, tsunamis , chemical and bacterial military tests, these effects affect human life.

It is not a secret for anyone now that these processes pose before humanity the question of how long it is possible to live on earth from now on. Because they say that not only natural resources, energy resources are being reduced, even a person in this environment is deprived of breathing fresh air, sources of pure nutrients, rivers, forests, seas, oceans, and the sky, soil causes irreparable damage. That is, it is known that the more human abilities and civilization develop, the larger and deeper, the more comfortable it becomes, and the more technical it becomes an instrument of self-destruction of humanity from the means of exploiting nature.

\section{MATERIALS AND METHODS}

In general, the crisis of modern medicine is part of a gross anthropological crisis, which manifests itself in different views and principles. "Among them," says the wellknown Russian philosopher, academician V.S.
Stepin, "if there is a direct reason manifested in environmental pollution (due to chemical and radioactive effects) on the foundation of the genephony formed over millions of years of human evolution, then the latter are direct powerful changes occurring under the influence (of microbes and viruses that cause various diseases). However, in the society of the individual, the activity of natural subordinates (that is, natural selection), which serve to preserve this gene pool, has its own certain limits. For example, in wars with the task of selection, mostly healthy and able to leave offspring were exterminated. And modern social life, which is rapidly changing in conditions of non-destructive social situations and competition taking place in all spheres, aggravates the anthropological crisis with its stresses. And this leads not only to an increase in the number of diseases of the heart, blood vessels, oncology, but also mental disorders. In subsequent years, mental disorders such as depression (mental disorder), by the end of the 2oth century, became the most common disease of the beginning of the 21st century.

Without denying someone scientific and technical achievements, which now seem to be only a positive phenomenon, we can now emphasize that civilization has come to a completely new opinion, thanks to these achievements, not only thinkers, representatives of the humanitarian sphere, but also many scientists themselves admit with great regret. For example, well-known Russian scientists write: the doctrine put into the hands of politicians a weapon capable of destroying life on the entire planet, not one, but several times, and, apparently, they did not try to determine how and what to do with them in the future, they acquired new ones. the energy sources with which they worked actively. They introduced a natural selection process for harmful microorganisms. 


\section{RESULT AND DISCUSSION}

But the unbridled vision of scientists of different categories continues to burn with enthusiasm for the creation of new inventions and technologies that are still unknown to mankind. They are now seriously interested in the majority of scientists, carry out research in such areas as nanotechnology, machine intelligence, genetic carriers of science, technology and are producing significant results. The director of the University of Oxford, Professor Nick Bostrom, says that at the same time they do not think about the negative consequences of the work done: thanks to the acceleration of technological progress, humanity is now more likely to approach a critical turning point of its development at a tremendous speed.

The nuclear threat, which has become well known to mankind, today is accompanied by meaningless opportunities and risks from rapidly developing technologies in areas such as nanotechnology and machine intelligence. Our future, if it exists, depends on our attitude to these processes.

In our opinion, it is obvious that the work carried out by genetic scientists at the present time to change the biological basis of a person leads to the onset of an anthropological crisis. Because, as a result of studying genomes, scientists get the opportunity not only to treat hereditary human diseases, but also artificially (implicitly not evolutionarily) unnatural (mental and physical) abilities). They still have definite results regarding the hereditary increase in hemoglobin in human blood. This means that doping, which is already banned for use by athletes in games, scientists were able to influence people of their choice. And who they choose depends either on themselves or on the wishes of their owners, more precisely on their morality, spirituality, and worldview. However, demonstrators of science, as we said above, are usually indifferent to questions of spirituality, morality, humanism.

While the famous Russian cultural figure Alexey Batalov feels with deep sorrow how these conditions affect the spirituality of a person, a family, and this situation is even worse than in the days of the former Soviet Union, he says: "I am deeply saddened by the fact that today people are becoming slaves to money. People change very quickly before our eyes. Is it possible that the granddaughter can push the grandmother out of the apartment. I grew up in an environment where people could maintain their humanity, even under extreme conditions. If there were no such people around me, perhaps I was a different person too. However, this artist thinks so vividly about a small introduction that the entire landscape reveals itself. Of course, it should also be that the famous actor belongs to a generation that lived sex under the influence of a generation that enjoyed the spiritual heritage of the former. For him, this little incident in which he is a hattoki is also a big evil.

\section{CONCLUSION}

From a philosopher's point of view, in order to solve all the problems listed above, it is worth knowing what lies at their root. In our opinion, there is only one common reason underlying them. Even if, as we said above, creation is not just a technique based on the psychology of consumption, technical civilization is in the order of the violent management of the economic economy. 


\section{REFERENCES}

1. Shermukhamedova N. Philosophy and methodology of science. - Tashkent:

University, 2005. - P. 361.

2. Utepin B.S. philosopher V.I. change. // Bulletin of Moscow University. Series 7. Philosophy. Number 4. 2006. -P. 1834.

3. Kapitsa S.P., Gordyumav S.P., Malinsky G.G. synergy and forecast of the future. 2ae. Mockow.: 2001. -P.305

4. Nick Bostrom - Ph.D., Director of the Institute for a New Future of Humanity, Oxford University. Throw a man's torment on you. Analysis of the scriptwriter vimiriya. // 2007.

http: //www/nickbostrom.com

5. Batalov A. fistula are given by wet Spain / / argument i fact. It is now 2008. Quantity 47.5-b.

6. Abdumalikov, Abdulatif Abidjanovich. "Human and natural harmony in the historical process." Scientific Bulletin of Namangan State University 1.5 (2019): 205-209. 